\title{
ANALISIS PERBANDINGAN KINERJA REKSA DANA SAHAM DAN REKSA DANA PENDAPATAN TETAP YANG TERDAFTAR DI OTORITAS JASA KEUANGAN
}

\author{
Desmizar \\ Universitas Mercu Buana
}

Email: mdesmizar@yahoo.com

\begin{abstract}
ABSTRAK
Penelitian ini bertujuan untuk membandingkan kinerja antara reksa dana saham dan reksa dana pendapatan tetap yang terdaftar di Otoritas Jasa Keuangan (OJK). Periode data yang digunakan dalam penelitian ini berada dalam rentang Juni 2018 - Mei 2019. Data berasal dari 32 sampel, baik reksa dana saham maupun reksa dana pendapatan tetap, yang dipilih dengan menggunakan metode simple random sampling. Hasil penelitian menunjukkan bahwa tidak terdapat perbedaan yang signifikan antara Nilai Aktiva Bersih (NAB) dan return yang dihasilkan oleh reksa dana saham dan reksa dana pendapatan tetap. Akan tetapi, hasil penelitian juga menunjukkan adanya perbedaan yang signifikan pada risiko (standar deviasi) dan Risk Adjusted Return (RAR) di antara reksa dana saham dengan reksa dana pendapatan tetap.
\end{abstract}

Kata kunci: Reksa dana saham, reksa dana pendapatan tetap, Nilai Aktiva Bersih (NAB), return, risiko (standar deviasi), Risk Adjusted Return (RAR)

\section{ABSTRACT}

This study aims to compare the performance between equity funds and fixed income mutual funds listed in the Financial Services Authority (OJK). The data period used in this study is in the range of June 2018 - May 2019. The data comes from 32 samples, both equity funds and fixed income mutual funds, which were selected using the simple random sampling method. The results showed that there was no significant differences in Net Asset Value (NAV) and return generated by equity funds and fixed income mutual funds. However, the results also showed that there was significant differences in risk (standard deviation) and Risk Adjusted Return (RAR) between equity funds and fixed income mutual funds.

Keywords: Equity mutual funds, fixed income mutual funds, Net Asset Value (NAV), return, risk (standard deviation), Risk Adjusted Return (RAR)

\section{PENDAHULUAN}

Investasi telah bertransformasi menjadi suatu kebutuhan yang penting bagi masyarakat modern. Dalam berinvestasi ini, setiap investor senantiasa mengharapkan keuntungan yang besar, namun keuntungan yang besar dari suatu investasi umumnya disertai dengan risiko yang besar pula. Oleh karena itu, setiap investor perlu memperhatikan aspek risiko dan tingkat pengembalian dari investasi yang akan dilakukannya. 
Salah satu instrumen pasar modal yang saat ini tengah berkembang pesat adalah reksa dana. Reksa dana merupakan salah satu alternatif investasi bagi masyarakat pemodal, khususnya pemodal kecil dan pemodal yang tidak memiliki waktu dan keahlian untuk menghitung risiko atas investasi mereka. Reksa dana juga menawarkan return yang lebih tinggi dibandingkan dengan bunga deposito. Reksa dana dikelola oleh manajer investasi yang bertugas untuk mencari kombinasi investasi yang dapat memberi keuntungan yang optimal bagi investor. Manajer investasi juga harus melakukan diversifikasi pada investasinya untuk meminimalkan risiko yang dihadapi oleh investor.

Hingga saat ini terdapat 92 manajer investasi yang terdaftar di Otoritas Jasa Keuangan (OJK). Masing-masing manajer investasi tersebut memiliki berbagai jenis produk reksa dana. Reksa dana yang memiliki produk terbanyak adalah reksa dana konvensional, yakni sebanyak 932 produk, kemudian diikuti oleh reksa dana terproteksi sebanyak 432 produk, reksa dana syariah sebanyak 134 produk, dan reksa dana indeks sebanyak 20 produk. Secara umum, reksa dana konvensional itu sendiri terbagi lagi menjadi empat jenis, yaitu reksa dana saham, reksa dana pendapatan tetap, reksa dana campuran, dan reksa dana pasar uang.

Setiap produk reksa dana memiliki Nilai Aktiva Bersih (NAB) yang berbeda, tak terkecuali untuk kedua produk reksa dana konvensional yang telah disebutkan sebelumnya, yaitu reksa dana saham dan reksa dana pendapatan tetap. NAB reksa dana itu sendiri dapat diartikan sebagai harga dari suatu reksa dana. Kenaikan dan penurunan NAB ini akan memberikan dampak pada nilai return dan tingkat risiko yang akan diterima. Dalam melakukan investasi, investor tentunya juga akan memperhatikan tingkat pengembalian (return) dari investasi yang akan dipilihnya. Setelah itu, tentunya investor akan melihat besaran risiko dari setiap jenis produk reksa dana, baru kemudian mengukur kinerja dari reksa dana yang bersangkutan yang salah satunya dapat dilakukan dengan menggunakan Risk-Adjusted Return (RAR) yang merupakan konsep pengukuran kinerja portofolio yang menggabungkan tingkat pengembalian dan risiko dalam sebuah perhitungan, sehingga dapat diketahui seberapa besar risiko yang terlibat untuk menghasilkan keuntungan tertentu.

Oleh karena setiap bentuk reksa dana dapat memiliki kinerja yang berbeda satu sama lainnya, maka perlu dilakukan penelitian yang membandingkan kinerja antara kedua jenis reksa dana konvensional, yaitu reksa dana saham dan reksa dana pendapatan tetap yang terdaftar di Otoritas Jasa Keuangan (OJK) yang diukur dengan menggunakan NAB, return, risiko (standar devasi), dan RAR. 


\section{TINJAUAN PUSTAKA}

\section{Reksa Dana}

Berdasarkan pasal 1 ayat 27 Undang-Undang Nomor 8 Tahun 1995, reksa dana didefinisikan sebagai wadah yang digunakan untuk menghimpun dana dari masyarakat pemodal untuk selanjutnya diinvestasikan dalam portofolio efek oleh manajer investasi. Keuntungan yang diperoleh adalah berupa kenaikan nilai investasi masyarakat pemodal seiring dengan berjalannya waktu periode investasi (Manurung, 2008). Berdasarkan pengertian tersebut, dapat disimpulkan bahwa reksa dana merupakan portofolio efek (saham, obligasi) yang disusun oleh manajer investasi sebagai sarana investasi bagi masyarakat.

Menurut Manurung (2008), reksa dana mempunyai beberapa karakteristik, yaitu sebagai berikut.

1. Kumpulan Dana Pemilik

Pemilik reksa dana adalah berbagai pihak yang menginvestasikan atau memasukkan dananya ke reksa dana dengan berbagai variasi. Hal ini berarti investor dari reksa dana dapat perseorangan dan lembaga dimana pihak tersebut melakukan investasi ke reksa dana sesuai dengan tujuan investor tersebut.

2. Diinvestasikan pada Efek yang Dikenal sebagai Instrumen Investasi

Dana yang dikumpulkan dari masyarakat tersebut diinvestasikan ke dalam instrumen investasi, seperti rekening koran, deposito, surat utang jangka pendek, surat utang jangka panjang, obligasi, dan efek saham. Manajer investasi melakukan investasi pada masing-masing instrumen tersebut dengan besaran yang berbedabeda sesuai perhitungan manajer investasi untuk mencapai tujuan investasi yaitu tingkat pengembalian yang diharapkan.

3. Reksa Dana Dikelola oleh Manajer Investasi

Manajer investasi ini dapat diperhatikan dari dua sisi, yaitu sebagai lembaga dan sebagai perseorangan. Sebagai lembaga, manajer investasi harus mempunyai izin perusahaan untuk mengelola dana, dimana izin tersebut diperoleh dari OJK bagi perusahaan yang bergerak dan berusaha di Indonesia. Perusahaan tersebut harus mempunyai izin sebagai pengelola dana.

4. Reksa Dana Merupakan Instrumen Investasi Jangka Menengah dan Jangka Panjang

Karakteristik keempat ini merupakan karakteristik yang tidak tertulis secara jelas tetapi merupakan karakteristik yang tersirat dari konsep tersebut. Jangka menengah dan jangka panjang merupakan refleksi dari investasi reksa dana karena 
umumnya reksa dana melakukan investasi kepada instrument investasi, seperti Medium Term Notes (MTN), obligasi, dan saham. Melalui konsep karakteristik tersirat ini, reksa dana tidak dapat dianggap sebagai pesaing dari deposito produk perbankan. Adapun bank-bank yang sudah maju atau sudah memiliki priority banking akan menawarkan reksa dana sebagai produk investasi jangka panjang.

5. Reksa Dana Merupakan Produk Investasi yang Berisiko

Risiko reksa dana disebabkan oleh instrumen yang menjadi portofolio reksa dana tersebut dan pengelola reksa dana (manajer investasi) yang bersangkutan. Risiko reksa dana ini dapat disebabkan oleh perubahan harga instrumen portofolio dari waktu ke waktu. Misalnya, jika suatu reksa dana berisikan obligasi, maka ketika Bank Indonesia mengeluarkan kebijakan peningkatan suku bunga, harga obligasi tersebut akan mengalami penurunan.

Manajer Investasi yang mengelola portofolio juga bisa membuat reksa dana yang dikelolanya berisiko dengan tindakan yang disengaja atau tidak disengaja. Misalnya, ada dana tunai yang diinvestasikan ke reksa dana, sementara manajer investasi sedang mengadakan rapat seharian sehingga lupa melakukan penempatan dana yang membuat pengembalian reksa dana tersebut mengalami penurunan.

\section{NAB Reksa Dana}

Menurut Nofie (2008), NAB (Nilai Aktiva Bersih) adalah nilai pasar wajar suatu efek dan kekayaan lain dari reksa dana dikurangi dengan kewajiban (utang). NAB menunjukkan besarnya nilai aset atau jumlah dana yang dikelola dalam suatu reksa dana. Nilai Aktiva Bersih (NAB). Jumlah dana yang dikelola tersebut umumnya sudah mencakup kas, deposito, saham, dan obligasi dengan menggunakan istilah AUM (Asset Under Management). NAB reksa dana ini juga dapat diartikan sebagai harga dari suatu reksa dana.

Dalam kaitannya dengan reksa dana, ada istilah yang disebut unit penyertaan, yaitu satuan yang digunakan dalam investasi reksa dana. NAB yang dibagi dengan unit penyertaan (NAB/UP) menyatakan harga wajar dari portofolio suatu reksa dana setelah dikurangi biaya operasional kemudian dibagi jumlah unit penyertaan yang telah dimiliki investor pada saat kegiatan transaksi dilakukan. Berbeda dengan saham dan obligasi, dimana investor sudah mengetahui berapa harga pada saat transaksi dilakukan, investor reksa dana baru mengetahui harga reksa dana pada keesokan harinya (Tricahyadinata, 2016). 


\section{Penilaian Kinerja Reksa Dana}

Penilaian kinerja reksa dana merupakan tahapan terakhir dalam suatu proses manajemen investasi. Kinerja reksa dana itu sendiri dapat diukur dengan hanya menghitung total return atau bahkan dengan turut melibatkan pengukuran risiko. Menurut Hartono (2010), return merupakan hasil yang diperoleh dari investasi selama periode tertentu. Return juga dapat diartikan sebagai keuntungan yang diperoleh investor dari dana yang ditanamkannya pada suatu investasi. Return itu sendiri dapat dibagi ke dalam return realisasi dan return ekspektasi. Return realisasi (realized return) merupakan return yang telah terjadi yang dihitung berdasarkan data historis sebagai salah satu pengukur kinerja dari reksa dana serta sebagai dasar penentuan return ekspektasi untuk mengukur risiko yang akan datang. Adapun return ekspektasi (expected return) adalah return yang diharapkan akan diperoleh investor di masa mendatang. Berbeda dengan return realisasi yang sifatnya sudah terjadi, return ekspektasi ini sifatnya belum terjadi.

Pengukuran kinerja yang dilakukan dengan melibatkan faktor risiko akan memberikan informasi yang lebih mendalam bagi investor tentang sejauh mana suatu hasil atau kinerja yang diberikan oleh manajer investasi dikaitkan dengan risiko yang diambil untuk mencapai kinerja tersebut. Risiko itu sendiri dapat didefinisikan sebagai perbedaan antara tingkat pengembalian aktual dengan tingkat pengembalian yang diharapkan. Menurut Hanafi (2006), risiko merupakan bahaya akibat atau konsekuensi yang dapat terjadi akibat sebuah proses yang sedang berlangsung atau kejadian yang akan datang. Manurung (2008) menjelaskan ada beberapa risiko yang dihadapi oleh investor, di antaranya adalah sebagai berikut.

1. Risiko ekonomi saat ini, yakni risiko terkait situasi ekonomi yang dapat memengaruhi NAB reksa dana.

2. Risiko berfluktuasinya NAB, yakni risiko yang terjadi karena adanya perubahan portofolio maupun kebijakan pemerintah atas tingkat bunga yang tidak dapat dikendalikan oleh manajer investasi.

3. Risiko likuiditas, yaitu risiko yang menunjukkan ketidakmampuan reksa dana untuk membayar karena portofolio yang tidak dapat dijual atau adanya investor yang sekaligus melakukan pencairan reksa dana.

4. Risiko pertanggungan atas harta atau kekayaan reksa dana, yaitu risiko yang dihadapi investor yang disebabkan oleh perubahan NAB karena adanya instrumen investasi yang tidak dibayar sebagai akibat dari adanya bencana alam sehingga diperlukan asuransi oleh bank kustodian. 
Pengukuran kinerja reksa dana juga dapat dilakukan dengan menggunakan Risk Adjusted Return (RAR), yaitu dengan membagi return reksa dana dengan risiko yang dihasilkan reksa dana (standar deviasi). Semakin besar nilai RAR dari suatu reksa dana, maka semakin baik pula kinerja dari reksa dana tersebut karena terbukti memberikan return yang tinggi atas risiko yang ditanggungnya.

\section{Hipotesis Penelitian}

Hipotesis penelitian ini dirumuskan sebagai berikut.

$\mathrm{H}_{1}$ : Terdapat perbedaan yang signifikan antara NAB reksa dana saham dan NAB reksa dana pendapatan tetap.

$\mathrm{H}_{2}$ : Terdapat perbedaan yang signifikan antara return reksa dana saham dan return reksa dana pendapatan tetap.

$\mathrm{H}_{3}$ : Terdapat perbedaan yang signifikan antara risiko reksa dana saham dan risiko reksa dana pendapatan tetap.

$\mathrm{H}_{4}$ : Terdapat perbedaan yang signifikan antara RAR reksa dana saham dan RAR reksa dana pendapatan tetap.

\section{METODOLOGI PENELITIAN}

\section{Populasi dan Sampel}

Populasi penelitian ini adalah manajer investasi reksa dana yang terdaftar di OJK selama periode penelitian yang memiliki produk reksa dana konvensional berjenis saham dan pendapatan tetap, yakni sebanyak 47 manajer investasi. Adapun periode data yang digunakan dalam penelitian ini berada dalam rentang Juni 2018 - Mei 2019. Dalam mengukur jumlah sampel yang akan diambil, peneliti menggunakan rumus Slovin dengan margin of error sebesar $10 \%$.

Setelah mengetahui jumlah sampel yang akan diambil, yaitu yang terdiri dari 32 manajer investasi, selanjutnya peneliti menggunakan teknik simple random sampling untuk memilih sampel yang akan diteliti. Teknik simple random sampling itu sendiri merupakan teknik pengambilan sampel dari anggota populasi yang dilakukan secara acak dengan tanpa memperhatikan strata yang ada dalam populasi tersebut.

\section{Variabel Penelitian}

Variabel independen yang digunakan dalam penelitian ini adalah variabel dummy dengan skala nominal pengkodean 0 dan 1 dimana kode 0 menunjukkan reksa dana saham 
dan kode 1 menunjukkan reksa dana pendapatan tetap. Adapun variabel dependen yang digunakan dalam penelitian ini antara lain sebagai berikut.

1. NAB Reksa Dana

NAB adalah besaran nilai yang menggambarkan harga dari suatu reksa dana. Dalam penelitian ini perkembangan Data yang digunakan dalam penelitian ini adalah rata-rata $\mathrm{NAB}$ reksa dana per triwulan.

2. Return Reksa Dana

Dalam penelitian ini, return reksa dana diartikan sebagai perbandingan antara selisih NAB reksa dana pada periode saat ini dan periode sebelumnya dengan NAB reksa dana pada periode sebelumnya.

$$
R_{r d}=\frac{\mathrm{NAB}_{\mathrm{t}}-\mathrm{NAB}_{\mathrm{t}-1}}{\mathrm{NAB}_{\mathrm{t}-1}}
$$

(Sumber: Hartono, 2010)

Keterangan:

$\mathrm{R}_{\mathrm{rd}} \quad=$ Return reksa dana

$\mathrm{NAB}_{\mathrm{t}}=\mathrm{NAB}$ reksa dana pada periode saat ini

$\mathrm{NAB}_{\mathrm{t}-1}=\mathrm{NAB}$ reksa dana pada periode sebelumnya

3. Risiko Reksa Dana

Risiko reksa dana dalam penelitian ini dihitung dengan menggunakan standar deviasi, yakni ukuran yang menggambarkan penyimpangan dari rata-rata return yang dihasilkan pada reksa dana.

$$
\sigma=\sqrt{\frac{\sum\left(R_{r d}-\overline{R_{r d}}\right)^{2}}{N-1}}
$$

(Sumber: Hartono, 2010)

Keterangan:

$$
\begin{array}{ll}
\sigma & =\text { Risiko (standar deviasi) reksa dana } \\
\mathrm{R}_{\mathrm{rd}} & =\text { Return reksa dana ke } \mathrm{i} \\
\overline{\mathrm{R}_{\mathrm{rd}}} & =\text { Rata-rata } \text { return } \\
\mathrm{N} & =\text { Jumlah pengamatan }
\end{array}
$$

4. RAR Reksa Dana

Dalam penelitian ini, RAR merupakan rasio antara return dan standar deviasi reksa dana. 


$$
\operatorname{RAR}=\frac{\mathrm{R}_{\mathrm{rd}}}{\sigma}
$$

(Sumber: Rudiyanto, 2011)

Keterangan:

$$
\begin{array}{ll}
\mathrm{RAR} & =\text { Nilai kinerja reksa dana } \\
\mathrm{R}_{\mathrm{rd}} & =\text { Return reksa dana } \\
\sigma & =\text { Standar deviasi reksa dana }
\end{array}
$$

\section{Metode Analisis}

Penelitian ini menggunakan metode uji beda regresi dengan variabel dummy untuk menguji hipotesis. Akan tetapi, normalitas data diuji terlebih dahulu dengan menggunakan metode Shapiro-Wilk berdasarkan pada besaran probabilitas atau nilai signifikansi.

\section{HASIL DAN PEMBAHASAN}

\section{Hasil Uji Normalitas}

Hasil uji Shapiro-Wilk menunjukkan angka signifikansi untuk reksa dana saham sebesar 0,116 dan untuk reksa dana pendapatan tetap sebesar 0,325 dengan tingkat signifikansi yang berarti di atas 0,05. Hal tersebut menunjukkan bahwa data dari sampel reksa dana saham dan reksa dana pendapatan tetap telah terdistribusi secara normal.

\section{Hasil Perbandingan NAB Reksa Dana Saham dan Pendapatan Tetap}

Tabel 1. Hasil Uji Regresi dengan Variabel Dummy

NAB Reksa Dana Saham dan Pendapatan Tetap

\begin{tabular}{|l|r|r|r|r|r|}
\hline \multirow{2}{*}{ Model } & \multicolumn{2}{|c|}{$\begin{array}{c}\text { Unstandardized } \\
\text { Coefficients }\end{array}$} & $\begin{array}{l}\text { Standardized } \\
\text { Coefficients }\end{array}$ & \multirow{2}{*}{ T } & \multirow{2}{*}{ Sig. } \\
\cline { 2 - 5 } & \multicolumn{1}{|c|}{ B } & Std. Error & \multicolumn{1}{c|}{ Beta } & & \\
\hline (Constant) & $1.261,644$ & 23,110 & & 54,592 & 0,000 \\
Dummy & 13,572 & 32,683 & 0,026 & 0,415 & 0,678 \\
\hline
\end{tabular}

(Sumber: Data diolah, 2019)

Besarnya hasil hitung rata-rata NAB reksa dana saham adalah Rp1.261,64. Dengan selisih sebesar Rp13.572 dari rata-rata NAB reksa dana saham tersebut, maka besarnya hasil hitung rata-rata NAB reksa dana pendapatan tetap adalah Rp1.275,216. Hasil uji statistik menggunakan analisis regresi dengan variabel dummy menunjukkan signifikansi sebesar 0,678, sehingga $\mathrm{H}_{0}$ terbukti diterima dan $\mathrm{H}_{1}$ ditolak karena $p$-value $>0,05$. Hal ini menunjukkan bahwa selisih antara rata-rata kinerja NAB reksa dana saham dengan rata- 
rata kinerja NAB reksa dana pendapatan tetap memiliki nilai yang tidak nyata. Dengan demikian, dapat disimpulkan bahwa tidak terdapat perbedaan yang signifikan antara kinerja NAB yang dihasilkan reksa dana saham dengan kinerja NAB yang dihasilkan reksa dana pendapatan tetap.

\section{Hasil Perbandingan Return Reksa Dana Saham dan Pendapatan Tetap}

Tabel 2. Hasil Uji Regresi dengan Variabel Dummy

Return Reksa Dana Saham dan Pendapatan Tetap

\begin{tabular}{|l|r|r|r|r|r|}
\hline \multirow{2}{*}{ Model } & \multicolumn{2}{|c|}{$\begin{array}{c}\text { Unstandardized } \\
\text { Coefficients }\end{array}$} & $\begin{array}{c}\text { Standardized } \\
\text { Coefficients }\end{array}$ & \multirow{2}{*}{ T } & \multirow{2}{*}{ Sig. } \\
\cline { 2 - 4 } & \multicolumn{1}{|c|}{ B } & Std. Error & \multicolumn{1}{c|}{ Beta } & & \\
\hline (Constant) & 0,871 & 0,394 & & 2,208 & 0,028 \\
Dummy & 0,540 & 0,558 & 0,061 & 0,968 & 0,334 \\
\hline
\end{tabular}

(Sumber: Data diolah, 2019)

Besarnya hasil hitung rata-rata return reksa dana saham adalah $0,871 \%$. Dengan selisih sebesar $0,540 \%$ dari rata-rata return reksa dana saham tersebut, maka besarnya hasil hitung rata-rata return reksa dana pendapatan tetap adalah 1,411\%. Hasil uji statistik menggunakan analisis regresi dengan variabel dummy menunjukkan signifikansi sebesar 0,334, sehingga $\mathrm{H}_{0}$ terbukti diterima dan $\mathrm{H}_{2}$ ditolak karena $p$-value $>0,05$. Hal ini menunjukkan bahwa selisih antara rata-rata kinerja return reksa dana saham dengan ratarata kinerja return reksa dana pendapatan tetap memiliki nilai yang tidak nyata. Dengan demikian, dapat disimpulkan bahwa tidak terdapat perbedaan yang signifikan antara kinerja return yang dihasilkan reksa dana saham dengan kinerja return yang dihasilkan reksa dana pendapatan tetap.

\section{Hasil Perbandingan Risiko Reksa Dana Saham dan Pendapatan Tetap}

Tabel 3. Hasil Uji Regresi dengan Variabel Dummy

Risiko Reksa Dana Saham dan Pendapatan Tetap

\begin{tabular}{|l|r|r|r|r|r|}
\hline \multirow{2}{*}{ Model } & \multicolumn{2}{|c|}{$\begin{array}{c}\text { Unstandardized } \\
\text { Coefficients }\end{array}$} & $\begin{array}{c}\text { Standardized } \\
\text { Coefficients }\end{array}$ & \multirow{2}{*}{ T } & \multirow{2}{*}{ Sig. } \\
\cline { 2 - 4 } & \multicolumn{1}{|c|}{ B } & Std. Error & \multicolumn{1}{c|}{ Beta } & & \\
\hline (Constant) & 2,526 & 0,183 & & 13,822 & 0,000 \\
Dummy & $-1,354$ & 0,258 & $-0,312$ & $-5,237$ & 0,000 \\
\hline
\end{tabular}

(Sumber: Data diolah, 2019) 
Besarnya hasil hitung rata-rata risiko reksa dana saham adalah 2,526\%. Dengan selisih sebesar $-1,354 \%$ dari rata-rata risiko reksa dana saham tersebut, maka besarnya hasil hitung rata-rata risiko reksa dana pendapatan tetap adalah $1,172 \%$. Hasil uji statistik menggunakan analisis regresi dengan variabel dummy menunjukkan signifikansi sebesar 0,000, sehingga $\mathrm{H}_{3}$ terbukti diterima karena $p$-value $<0,05$. Hal ini menunjukkan bahwa selisih antara rata-rata risiko reksa dana saham dengan rata-rata risiko reksa dana pendapatan tetap memiliki nilai yang nyata. Dengan demikian, dapat disimpulkan bahwa terdapat perbedaan yang signifikan antara risiko reksa dana saham dengan risiko reksa dana pendapatan tetap.

\section{Hasil Perbandingan RAR Reksa Dana Saham dan Pendapatan Tetap}

Tabel 4. Hasil Uji Regresi dengan Variabel Dummy

RAR Reksa Dana Saham dan Pendapatan Tetap

\begin{tabular}{|l|r|r|r|r|r|}
\hline \multirow{2}{*}{ Model } & \multicolumn{2}{|c|}{$\begin{array}{c}\text { Unstandardized } \\
\text { Coefficients }\end{array}$} & $\begin{array}{c}\text { Standardized } \\
\text { Coefficients }\end{array}$ & \multirow{2}{*}{ T } & \multirow{2}{*}{ Sig. } \\
\cline { 2 - 5 } & \multicolumn{1}{|c|}{ B } & Std. Error & \multicolumn{1}{c|}{ Beta } & & \\
\hline (Constant) & 0,361 & 0,159 & & 2,275 & 0,024 \\
Dummy & 1,248 & 0,224 & 0,329 & 5,562 & 0,000 \\
\hline
\end{tabular}

(Sumber: Data diolah, 2019)

Besarnya hasil hitung rata-rata RAR reksa dana saham adalah 0,361. Dengan selisih sebesar 1,248 dari rata-rata RAR reksa dana saham tersebut, maka besarnya hasil hitung rata-rata RAR reksa dana pendapatan tetap adalah 1,609. Hasil uji statistik menggunakan analisis regresi dengan variabel dummy menunjukkan signifikansi sebesar 0,000, sehingga $\mathrm{H}_{4}$ terbukti diterima karena $p$-value $<0,05$. Hal ini menunjukkan bahwa selisih antara rata-rata RAR reksa dana saham dengan rata-rata RAR reksa dana pendapatan tetap memiliki nilai yang nyata. Dengan demikian, dapat disimpulkan bahwa terdapat perbedaan yang signifikan antara RAR reksa dana saham dengan RAR reksa dana pendapatan tetap. 


\section{KESIMPULAN DAN SARAN}

\section{Kesimpulan}

Berdasarkan analisis yang telah dilakukan, dapat ditarik kesimpulan sebagai berikut.

1. Tidak terdapat perbedaan yang signifikan antara NAB yang dihasilkan reksa dana saham dengan NAB yang dihasilkan reksadana pendapatan tetap.

2. Tidak terdapat perbedaan yang signifikan antara return yang dihasilkan reksa dana saham dengan return yang dihasilkan reksadana pendapatan tetap.

3. Terdapat perbedaan yang signifikan antara risiko reksa dana saham dengan risiko reksadana pendapatan tetap.

4. Terdapat perbedaan yang signifikan antara RAR reksa dana saham dengan RAR reksadana pendapatan tetap.

\section{Saran}

Saran yang dapat dipertimbangkan oleh investor berkaitan dengan hasil penelitian ini antara lain sebagai berikut.

1. Investor yang akan menginvestasikan uangnya pada reksa dana disarankan untuk melihat perkembangan data masa lalu dari reksa dana yang akan dipilih agar dapat menjadi pertimbangan saat memilih produk reksa dana, sehingga dapat meminimalisir risiko yang akan terjadi pada investasi reksa dana tersebut. Reksa dana pendapatan tetap bisa menjadi pertimbangan bagi para investor, khususnya investor Indonesia yang umumnya baru belajar berinvestasi. Hal ini dikarenakan reksa dana pendapatan tetap terbukti menghasilkan RAR yang secara signifikan lebih besar daripada reksa dana saham.

2. Penelitian ini hanya berlaku pada reksa dana konvensional yang berjenis reksa dana saham dan reksa dana pendapatan tetap, sehingga tidak mencakup reksa dana yang sejenis, seperti reksa dana saham syariah dan reksa dana pendapatan tetap syariah. Oleh karena itu, peneliti merekomendasikan agar peneliti selanjutnya melakukan perbandingan pada reksa dana saham syariah dan reksa dana pendapatan tetap syariah. 


\section{DAFTAR PUSTAKA}

Ghozali, I. 2016. Aplikasi Analisis Multivariate dengan Program IBM SPSS 21. Badan Penerbit Universitas Diponegoro. Semarang.

Hanafi, M. 2006. Manajemen Risiko. Unit Penerbitan Sekolah Tinggi Ilmu Manajemen YKPN. Yogyakarta.

Hartono, J. 2010. Teori Portofolio dan Analisis Investasi. BPFE UGM. Yogyakarta.

Manurung, A.H. 2008. Reksa Dana Investasiku. Kompas Media. Jakarta.

Nofie, I. 2008. Panduan Singkat dan Praktis: Memulai Investasi Reksadana. PT Elex Media Komputindo. Jakarta.

Praja, G.D. 2015. Analisis Komparasi Kinerja Portofolio Reksa Dana Saham Syariah dan Reksa Dana Saham Konvensional dengan Metode Sharpe. Skripsi. Fakultas Ekonomi dan Bisnis Universitas Lampung. Bandar Lampung.

Pratomo, E.P. dan U. Nugraha. 2009. Reksa Dana: Solusi Perencanaan Investasi di Era Modern Edisi Kedua. PT Gramedia Pustaka Utama. Jakarta.

Putra, J. dan S. Fauzie. 2014. Analisis Perbandingan Kinerja Reksa Dana Konvensional dengan Reksa Dana Syariah di Indonesia. Jurnal Ekonomi dan Keuangan. 2(5): 282-295.

Qomariah, N., M.I. Sari, dan D.A. Budiarti. 2016. Perbandingan Kinerja Reksa Dana Syariah dan Reksa Dana Konvensional pada Reksa Dana Saham dan Reksa Dana Pendapatan Tetap yang Terdaftar di BEI Periode 2010-2014. Jurnal Keuangan dan Perbankan. 20(3): 417-427.

Rahmawanti, D. 2016. Analisis Perbandingan Kinerja Reksa Dana Konvensional dengan Reksa Dana Syariah Periode 2013-2014. Skripsi. Universitas Lampung. Bandar Lampung.

Rudiyanto. 2011. Metode Evaluasi Kinerja Reksa Dana. http://rudiyanto. blog.kontan.co.id/2011/05/16/mengenal-metodeevaluasi-kinerja-reksadana/comment-page-10/.

Simforianus dan Y. Hutagaol. 2008. Analisis Kinerja Reksa Dana Saham dengan Metode Raw Return, Sharpe, Treynor, Jensen, dan Sortino. Journal of Applied Finance and Accounting. 1(1): 193-226.

Solkhan, M. 2015. Analisis Perbandingan Kinerja Reksa Dana Saham, Pendapatan Tetap, dan Campuran dengan Kinerja Pasar dengan Menggunakan Metode Sharpe dan Treynor. Skripsi. Universitas Islam Negeri Walisongo. Semarang.

Tandelilin, E. 2007. Analisis Investasi dan Manajemen Portofolio. BPFE. Yogyakarta. 
Tricahyadinata, I. 2016. Indeks Harga Saham Gabungan dan Jakarta Interbank Offered Rate: Kinerja Reksa Dana Campuran. Inovasi: Jurnal Ekonomi Keuangan dan Manajemen. 12(2): 281-310.

Undang-Undang Republik Indonesia Nomor 8 Tahun 1995. Pasar Modal. 10 November 1995. Lembaran Negara Republik Indonesia Tahun 1995 Nomor 64. Jakarta.

Wijaya, T. dan Juwita. 2012. Analisis Kinerja Reksa Dana Saham dan Kinerja Reksa Dana Terproteksi. Jurnal Keuangan.

https://www.bi.go.id.

https://www.infovesta.com

https://www.ojk.go.id

https://www.pusatdata.kontan.co.id/reksadana 